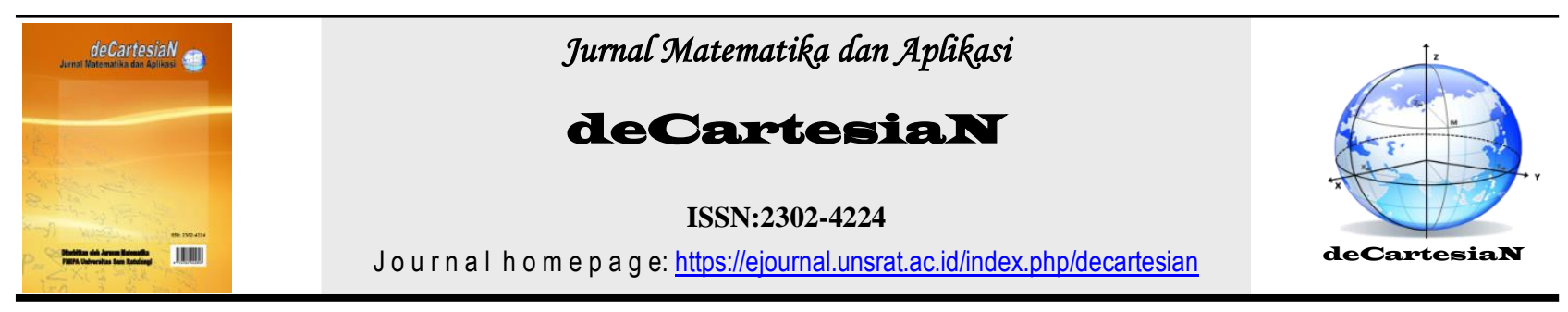

\title{
Analisis Hubungan IHK (Indeks Harga Konsumen) dan Kurs Beli IDR-USD Melalui Pendekatan Copula
}

\author{
Elvina Luxviantono ${ }^{1}$, Adi Setiawan ${ }^{1}$, Leopoldus Ricky Sasongko ${ }^{1 *}$ \\ ${ }^{1}$ Program Studi Matematika-Fakultas Sains dan Matematika-Universitas Kristen Satya Wacana, Jln. Diponegoro No. 52-60, \\ Salatiga 50711, Indonesia \\ *Corresponding author : leopoldus.sasongko@staff.uksw.edu.
}

\begin{abstract}
A B S T R A K
Salah satu metode yang dapat digunakan untuk menganalisis keterhubungan antar dua peubah acak adalah metode dengan pendekatan copula. Copula (bivariat) bersifat fleksibel dalam menjelaskan keterhubungan antar dua peubah acak yang tidak linier dan dapat menggambarkan perilaku data bivariat yang memiliki distribusi-distribusi marginal yang berbeda keluarga. Dalam penelitian ini dikaji hubungan antara Indeks Harga Konsumen (IHK) dan return Kurs Beli IDR-USD melalui metode pendekatan copula. Data yang digunakan pada penelitian ini adalah data (sekunder) bulanan mengenai IHK dan return Kurs Beli IDR-USD selama periode Mei 2012 sampai Juni 2017. Estimasi parameter distribusi-distribusi marginal (IHK dan return Kurs beli IDRUSD) didasarkan pada metode Maximum Likelihood Estimation (MLE) dan uji kecocokan distribusi-distribusi marginalnya didasarkan pada uji statistik Kolmogorov-Smirnov. Estimasi parameter copula yang cocok untuk menggambarkan keterhubungan data IHK dan return Kurs Beli IDR-USD didasarkan pada ukuran Kendall's Tau dan Spearman's Rho dari data tersebut. Hasil penelitian ini menunjukkan bahwa hubungan antara IHK dan return Kurs Beli IDR-USD berdasarkan ukuran Kendall's Tau dan Spearman's Rho adalah kecil yang berarti data saling bebas atau dengan arti lain hampir tidak memiliki keterhubungan. Sementara itu, keterhubungan IHK dan return Kurs Beli IDRUSD dapat digambarkan melalui suatu copula. Copula yang cocok untuk menggambarkan keterhubungan IHK dan return Kurs Beli IDR-USD sebagai hasil dalam bahasan paper ini adalah copula Clayton dengan distribusi marginal IHK adalah distribusi Laplace dan begitu pula distribusi marginal return Kurs Beli IDR-USD adalah distribusi Laplace. Dalam hal ini, copula Clayton itu adalah terbaik berdasarkan uji kecocokan copula yaitu melalui uji statistik Cramér-von Mises dengan nilai p-value tertinggi yang diperoleh dengan bantuan simulasi parametric bootstrap.
\end{abstract}

\author{
INFO ARTIKEL \\ Diterima $\quad: 23$ April 2018 \\ Diterima setelah revisi : 9 Mei 2018 \\ Tersedia online $\quad$ : 30 Juli 2018
}

\section{PENDAHULUAN}

Salah satu kegiatan ekonomi yang dikenal adalah perdagangan, suatu aktivitas jual-beli barang atau jasa. Suatu negara memiliki mata uang yang nilainya berbeda dengan mata uang negara lain (valuta asing) sehingga perbandingan antar nilai mata uang atau kurs menjadi faktor penting dalam perdagangan internasional.

Indeks harga konsumen (IHK) merupakan salah satu indikator ekonomi penting yang dapat memberikan informasi mengenai perkembangan harga barang dan jasa yang dibeli oleh konsumen secara umum dari waktu ke waktu. Perubahan IHK dari waktu ke waktu menunjukkan perubahan tingkat harga rata-rata tertimbang untuk barang dan jasa dalam perekonomian suatu negara yang dapat mengalami kenaikan (inflasi) atau penurunan (deflasi). Gejolak harga barang dan jasa di suatu wilayah sangat berpengaruh terhadap kondisi ekonomi masyarakat setempat [1]. Pada dasarnya kenaikan atau penurunan IHK memiliki dampak positif dan dampak negatif bagi perekonomian suatu negara apabila terjadi secara terus-menerus. IHK dapat digunakan untuk perhitungan tingkat inflasi atau deflasi yang mana sangat mempengaruhi kurs mata uang suatu negara terhadap valuta asing (valas), atau dengan arti lain, IHK dan kurs mata uang suatu negara terhadap valas memiliki keterhubungan. 
Perubahan IHK dapat mempengaruhi kegiatan perdagangan internasional karena adanya perbedaan harga sebagai dampak perubahan harga tersebut. Perubahan tersebut akan mempengaruhi permintaan dan penawaran mata uang sehingga mempengaruhi nilai tukar, misalnya jika IHK megalami kenaikan (inflasi) lebih tinggi daripada tingkat inflasi Amerika, maka akan memicu bertambahnya nilai impor sehingga nilai tukar Indonesian Rupiah (IDR) terhadap United States Dollar (USD) akan melemah. Tetapi tingkat inflasi berpengaruh positif terhadap pergerakan nilai tukar USD terhadap IDR, yang berarti bahwa jika IHK mengalami kenaikan maka arah pergerakan nilai tukar USD terhadap IDR juga akan meningkat. Sedangkan apabila IHK mengalami penurunan (deflasi) lebih tinggi dari tingkat deflasi Amerika, maka nilai ekspor akan bertambah sehingga nilai tukar IDR terhadap USD akan menguat dan pergerakkan nilai tukar USD terhadap IDR akan melemah. Fenomena ini menyebabkan keterhubungan IHK dan kurs menjadi penting untuk dikaji.

Keterhubungan antar dua peubah dapat diukur dengan koefisien korelasi Pearson dengan asumsi dua peubah tersebut memiliki hubungan linier. Dua peubah memiliki hubungan linier apabila perubahan dalam satu peubah dikaitkan dengan perubahan yang sebanding pada peubah lainnya. Jika hubungan dua peubah tidak linier maka ukuran keterhubungan Spearman's Rho atau Kendall's Tau dapat digunakan untuk menjelaskan hubungan tersebut. Berbeda dengan koefisien korelasi Pearson, ukuran keterhubungan ini tidak memerlukan asumsi normalitas dan data yang digunakan dapat berupa data kategorik (tingkat pendidikan, kelompok usia, kategori pekerjaan, dll) maupun data numerik (kurs rupiah, rasio keuangan, pertumbuhan ekonomi, dll). Pada umumnya, kasus-kasus yang distribusinya tidak normal tidak terlalu diperhatikan atau bahkan dipaksakan dengan asumsi berdistribusi normal. Oleh karena itu diperlukan metode yang dapat mengatasi permasalahan ini, salah satunya adalah dengan pendekatan copula.

Kajian mengenai copula telah banyak dilakukan, salah satunya oleh Anisa dan Sutikno pada [2] yang mana dengan menggunakan pendekatan copula pola hubungan curah hujan dan indikator ENSO di Jawa Timur pada time lag berbeda sebagian besar mengikuti copula Clayton dan Frank. Penelitian lain dilakukan oleh Heriyanto dan Ming Chen, pada [3] meneliti tentang pengaruh indeks harga konsumen (IHK), jumlah uang beredar (M1), kurs rupiah, dan indeks S\&P 500 terhadap indeks harga saham gabungan (IHSG) dengan menggunakan analisis regresi berganda menunjukkan bahwa variabel kurs rupiah terhadap dollar dan Indeks S\&P 500 berpengaruh signifikan terhadap pergerakan IHSG, sedangkan variabel IHK dan jumlah uang beredar tidak berpengaruh signifikan. Berdasarkan [4], copula adalah suatu fungsi dari dua/lebih hubungan distribusi yang masing-masing mempunyai fungsi marginal distribusi. Copula dapat digunakan untuk menggabungkan beberapa distribusi marginal menjadi distribusi bersama (bivariat/multivariat). Analisis hubungan melalui pendekatan copula mempunyai kelebihan yaitu dapat menjelaskan keterhubungan antar peubah-peubah yang distribusinya tidak normal.

Penelitian ini mengangkat bahasan mengenai IHK dan kurs beli IDR-USD sebagai peubah-peubah yang mempunyai keterhubungan. Keterhubungan tersebut akan dijelaskan melalui pendekatan copula, fungsi yang menggabungkan dua fungsi distribusi marginal peubah-peubahnya. Oleh karena itu, pada penelitian ini akan dikaji mengenai analisis hubungan IHK dan kurs beli IDR-USD melalui pendekatan copula.

\section{Transformasi Data}

Teknik transformasi data yang digunakan yaitu teknik differencing yang mana dapat membuat data menjadi stasioner. Stasioner merupakan suatu kondisi data apabila rata-rata dan variansi dari peubah-peubah tersebut tidak dipengaruhi oleh waktu [5]. Persamaan yang digunakan pada transformasi differencing dalam penelitian ini sebagai berikut:

dan

$$
X_{t}=I H K_{t-1}-I H K_{t}
$$

$$
Y_{t}=\operatorname{Kurs}_{t-1}-\operatorname{Kurs}_{t}
$$

dengan $I H K_{t}$ merupakan data IHK pada waktu $t$ dan $\operatorname{Kurs}_{t}$ merupakan data kurs beli IDR-USD pada waktu t.

\section{Ukuran Keterhubungan}

Ada 2 ukuran keterhubungan yang dikenal yaitu Kendall's Tau dan Spearman's Rho. Kendall's Tau didefinisikan Kendall's Tau didefinisikan sebagai probabilitas concordant dikurangi probabilitas discordant [4]. Kendall's Tau didefinisikan oleh

$$
\tau=P\left[\left(X_{1}-X_{2}\right)\left(Y_{1}-Y_{2}\right)>0\right]-P\left[\left(X_{1}-X_{2}\right)\left(Y_{1}-Y_{2}\right)<0\right] \text {. }
$$

Kendall's Tau digunakan untuk mencari hubungan antar dua peubah dengan data terdiri dari sampel acak bivariat $X$ dan $Y$ [4]. Kendall's Tau untuk sampel sebanyak $n$ didefinisikan sebagai berikut:

$$
\tau=\frac{c-d}{c+d}=\frac{(c-d)}{\left(\begin{array}{l}
n \\
2
\end{array}\right)} .
$$

Ukuran keterhubungan yang dikenal lainnya adalah Spearman's Rho, Misalkan $X$ dan $Y$ peubah acak kontinu dengan copula $C$, maka Spearman's Rho untuk $X$ dan $Y$ yang didefinisikan oleh [4] yaitu

$\rho=3\left(P\left[\left(X_{1}-X_{2}\right)\left(Y_{1}-Y_{3}\right)>0\right]-P\left[\left(X_{1}-X_{2}\right)\left(Y_{1}-Y_{3}\right)<0\right]\right) .(5)$ Untuk semua $n$ bilangan bulat yang berbeda dan menyatakan peringkat data, Spearman's Rho dapat dihitung melalui

$$
\rho=1-\frac{6 \sum_{i=1}^{n} d_{i}^{2}}{n\left(n^{2}-1\right)}
$$




\section{Goodness of Fit Test}

Goodness of fit test adalah uji kecocokan distribusi yang digunakan untuk mengukur tingkat kesesuaian atau kecocokan antara distribusi-distribusi marginal pada data penelitian dengan distribusi-distribusi tertentu.

\section{1. Maximum Likelihood Estimation (MLE)}

Dalam penelitian ini penaksiran parameter akan dilakukan dengan menggunakan metode Maximum Likelihood Estimation (MLE). Berdasarkan [6], fungsi likelihood untuk $n$ sampel acak $\boldsymbol{x}=\left\{x_{1}, x_{2}, x_{3}, \ldots, x_{n}\right\}$ didefinisikan pada persamaan berikut :

$$
L(x ; \Omega)=\prod_{i=1}^{n} f\left(x_{i} ; \Omega\right) .
$$

\section{2. Uji Kecocokan Distribusi Kolmogorov- Smirnov Satu Sampel}

Uji Kolmogorov-Smirnov merupakan salah satu uji goodness of fit (kecocokan) yang digunakan untuk menguji apakah data yang berskala minimal ordinal berasal dari distribusi tertentu. Uji Kolmogorov-Smirnov dapat dilakukan dengan menentukan hipotesis sebagai berikut

$H_{o}$ : data mengikuti distribusi parametrik $\hat{F}\left(x_{i} ; \Omega\right)$, $H_{1}$ : data tidak mengikuti distribusi parametrik $\hat{F}\left(x_{i} ; \Omega\right)$ Statistik uji Kolmogorov-Smirnov dinotasikan dengan $D_{n}$ yang mana menyatakan perbedaan terbesar antara fungsi distribusi empirik dan distribusi teoritis yang ingin diuji, didefinisikan oleh

$$
D_{n}=\max \left\{D_{n}^{-}, D_{n}^{+}\right\}
$$

dimana

$$
\begin{array}{r}
D_{n}^{-}=\max _{i=1, \ldots n}\left[\frac{i}{n}-\hat{F}\left(x_{i} ; \Omega\right)\right] ; \\
D_{n}^{+}=\max _{i=1, \ldots n}\left[\hat{F}\left(x_{i} ; \Omega\right)-\frac{i-1}{n}\right]
\end{array}
$$

dengan $x_{i}, i=1,2, \ldots, n$ (ordered statistic) adalah data yang telah diurutkan dari yang terkecil hingga yang terbesar.

\section{Copula}

Copula (bivariat) adalah suatu fungsi distribusi bivariat dengan marginal-marginalnya berdistribusi seragam [0,1] [7]. Copula $C$ didefinisikan oleh

$$
C(u, v)=\operatorname{Pr}[U \leq u, V \leq v]
$$

untuk $U$ dan $V$ berdistribusi seragam di [0,1]. Berdasarkan persamaan (3), maka Kendall's Tau dalam kaitannya dengan copula $C$ dinyatakan oleh

$$
\tau=4 \iint_{\mathrm{I}^{2}} C(u, v) d C(u, v)-1,
$$

sedangkan dalam kaitannya dengan copula $C$ berdasarkan persamaan (5), maka Spearman's Rho dinyatakan oleh

$$
\rho=12 \iint_{I^{2}} C(u, v) d C(u, v)-3 .
$$

\subsection{Copula Archimedean}

Salah satu keluarga copula adalah copula Archimedean. Copula Archimedean didefinisikan oleh

$$
\varphi_{\theta}(C(u, v))=\varphi_{\theta}(u)+\varphi_{\theta}(v)
$$

dengan fungsi $\varphi$ dikatakan sebagai generator copula, dan diasumsikan bahwa generator $\varphi$ hanya memiliki satu parameter, yaitu $\theta$ [5]. Estimasi parameter copula Archimedean $(\theta)$ dilakukan melalui Kendall's tau $(\tau)$, yang mana $\theta$ dapat diperoleh dengan mencari solusi persamaan (14)

$$
\tau=1+4 \int_{0}^{1} \frac{\varphi_{\theta}(t)}{\varphi_{\theta}^{\prime}(t)} d t
$$

Terdapat berbagai macam keluarga dari copula Archimedean yaitu copula Clayton, copula Frank, copula Gumbel, copula Ali-Mikhail-Haq dan yang lainnya.

Fungsi copula Clayton didefinisikan oleh

$$
C_{C, \theta}(u, v)=\left(u^{-\theta}+v^{-\theta}-1\right)^{-\frac{1}{\theta}}
$$

dengan $\theta \in(0, \infty)$. Fungsi generator untuk copula Clayton sebagai berikut

$$
\varphi_{\theta}(t)=\frac{1}{\theta}\left(t^{-\theta}-1\right)
$$

Parameter $\theta$ copula Clayton diperoleh dari persamaan (14) berdasarkan (16) adalah

$$
\theta=\frac{2 \tau}{1-\tau}
$$

dengan $\theta \epsilon(0, \infty)$.

Fungsi copula Gumbel didefinisikan oleh

$$
C_{G, \theta}(u, v)=\exp \left(-\left[(-\ln u)^{\theta}+(-\ln v)^{\theta}\right]^{\frac{1}{\theta}}\right)
$$

dan fungsi generator copula Gumbel adalah

$$
\varphi_{\theta}(t)=(-\ln t)^{\theta} .
$$

dengan $\theta \in[1, \infty)$. Parameter $\theta$ copula Gumbel dapat diperoleh dengan mencari solusi dari persamaan (14) berdasarkan (19), sehingga parameter $\theta$ adalah

$$
\theta=\frac{1}{1-\tau}
$$

Copula AMH (Ali-Mikhail-Haq) dinyatakan oleh

$$
C_{A, \theta}=\frac{u v}{1-\theta(1-u)(1-v)}
$$

dengan $\theta \in[-1,1)$. Fungsi generator copula AMH adalah

$$
\varphi_{\theta}(t)=\ln \left[\frac{1-\theta(1-t)}{t}\right]
$$

Estimasi parameter $\theta$ copula Ali-Mikhail-Haq dengan mencari solusi persamaan melalui metode numerik bagi dua, persamaan Kendall's Tau adalah

$$
\tau=\frac{3 \theta-2}{3 \theta}-\frac{2(1-\theta)^{2} \ln (1-\theta)}{3 \theta^{2}}
$$

Fungsi copula Frank didefinisikan oleh

$$
C_{F, \theta}(u, v)=-\frac{1}{\theta} \ln \left(1+\frac{\left(e^{-\theta u}-1\right)\left(e^{-\theta v}-1\right)}{e^{-\theta}-1}\right)
$$


dengan $\theta \in \mathbb{R} \backslash\{0\}$. Fungsi generator copula Frank adalah

$$
\varphi_{\theta}(t)=-\ln \left(\frac{e^{-\theta t}-1}{e^{-\theta}-1}\right) .
$$

Parameter $\theta$ copula Frank dapat diperoleh dengan mencari solusi dari persamaan Kendall's Tau melalui metode numerik bagi dua seperti yang dijelaskan pada [9], persamaan Kendall's Tau sebagai berikut

$$
\tau=1-\frac{4\left(1-\theta^{-1} \int_{0}^{\theta} \frac{t}{e^{t}-1} d t\right)}{\theta} .
$$

\subsection{Copula Plackett}

Keluarga Copula Plackett sering disebut constant global cross ratio distributions atau contingency-type distributions. Bentuk Copula Plackett adalah

$$
\begin{aligned}
C_{\mathrm{P}, \theta}(u, v)= & \frac{[1+(\theta-1)(u+v)]}{2(\theta-1)} \\
& -\frac{\sqrt{[1+(\theta-1)(u+v)]^{2}-4 u v \theta(\theta-1)}}{2(\theta-1)}
\end{aligned}
$$

untuk $0<\theta<\infty$ dan $\theta \neq 1$. Pada copula Plackett estimasi parameter $\theta$ dapat dilakukan melalui Spearman's $R$ ho yang mana $\theta$ dapat diperoleh dengan mencari solusi persamaan (28)

$$
\rho=\frac{\theta+1}{\theta-1}-\frac{2 \theta}{(\theta-1)^{2}} \ln \theta
$$

\subsection{Simulasi Pembangkitan Bilangan Acak Bi- variat Menggunakan Copula}

Prosedur untuk membangkitkan bilangan acak bivariat $\{(x)$,$\} dari suatu fungsi distribusi bivariat H$ dengan menggunakan copula berdasarkan persamaan berikut

$$
z_{u}(v)=\frac{\partial C(u, v)}{\partial u}
$$

dilakukan dengan melalui langkah-langkah berikut:

- Bangkitkan dua bilangan acak yang saling bebas $u$ dan $t$ yang berdistribusi seragam di $[0,1]$;

- $\quad$ Akan diperoleh $v=z_{u}{ }^{(-1)}(t)$, dengan $z_{u}{ }^{(-1)}$ merupakan invers fungsi dari $z_{u}$;

- $\quad$ Peroleh sepasang bilangan acak bivariat dari suatu copula yaitu $(x, y)$;

- $\quad$ Peroleh sepasang bilangan acak bivariat $(x, y)=$ $\left(F^{-1}(u), G^{-1}(v)\right)$

\subsection{Goodness of Fit Test for Copula}

Uji kecocokan untuk copula pada data dilakukan untuk mengetahui seberapa cocok copula dapat mencerminkan perilaku data. Uji kecocokan akan dilakukan berdasarkan proses empirik (empirical process) pada fungsi distribusi bivariat ataupun copula untuk parameter $\hat{\theta}$ dinyatakan oleh [8]

$$
\begin{aligned}
\mathrm{e}\left(x_{i}, y_{i}\right) & =\sqrt{n}\left[H_{e}\left(x_{i}, y_{i}\right)-H_{\widehat{\theta}}\left(x_{i}, y_{i}\right)\right] \\
& =\sqrt{n}\left[C_{e}\left(F\left(x_{i}\right), G\left(y_{i}\right)\right)-C_{\widehat{\theta}}\left(F\left(x_{i}\right), G\left(y_{i}\right)\right)\right]
\end{aligned}
$$

dengan $\quad H_{e}\left(x_{i}, y_{i}\right)=C_{e}\left(F\left(x_{i}\right), G\left(y_{i}\right)\right)=\frac{\#\left(x \leq x_{i}, y \leq y_{i}\right)}{n+1}$ adalah fungsi distribusi bivariat empiris atau Copula empiris untuk data, $\left\{\left(x_{i}, y_{i}\right)\right\}, i=1,2, \ldots, n$. Fungsi $\#(x \leq$ $\left.x_{i}, y \leq y_{i}\right)$ menyatakan banyaknya data bivariat $\left\{\left(x_{i}, y_{i}\right)\right\}$ dengan $x \leq x_{i}$ dan $y \leq y_{i}$.

Ukuran statistik yang digunakan adalah statistik Cramér-von Mises, yang diperoleh dari

$$
\begin{aligned}
S_{n} & =\sum_{i=1}^{n}\left[H_{e}\left(x_{i}, y_{i}\right)-H_{\widehat{\theta}}\left(x_{i}, y_{i}\right)\right]^{2} \\
& =\sum_{i=1}^{n}\left[C_{e}\left(F\left(x_{i}\right), G\left(y_{i}\right)\right)-H_{\widehat{\theta}}\left(F\left(x_{i}\right), G\left(y_{i}\right)\right)\right]^{2} .
\end{aligned}
$$

Kecocokan data terhadap suatu fungsi distribusi bivariat atau copula bergantung pada nilai statistik terkecil Cramér-von Mises $\left(S_{n}\right)$ terkecil dari beberapa fungsi distribusi bivariat atau copula yang dicocokkan. Nilai $p_{\text {value }}$ dapat diperoleh dari parametric bootstrap.

\subsection{Parametric Bootstrap untuk Ukuran Statistik Cramer-von Mises}

Ukuran statistik dan p-value Cramér-von Mises $\left(S_{n}\right)$ dapat diperoleh melalui metode simulasi parametric bootstrap [7]. Algoritma parametric bootstrap dijabarkan sebagai berikut:

Diketahui data bivariat sebanyak $n$ pasang yaitu $\left\{\left(x_{a}, y_{a}\right)\right\}, a=0,1,2,3, \ldots, n$. Untuk $N$ bilangan bulat positif sangat besar (digunakan 1000),

1. Bangkitkan $n$ sampel acak bivariat $\left\{\left(x_{i}, y_{i}\right)\right\}$ dengan $i=0,1,2, \ldots, n$ dari suatu distribusi bivariat $H_{\theta}(x, y)$ atau Copula $C_{\theta}(F(x), G(y))$,

2. Hitung $H_{e}\left(x_{i}, y_{i}\right)=C_{e}\left(F\left(x_{i}\right), G\left(y_{i}\right)\right)=$ $\frac{\#\left(x_{a} \leq x_{i}, y_{a} \leq y_{i}\right)}{n+1}$ dengan $\#\left(x_{a} \leq x_{i}, y_{a} \leq y_{i}\right)$ adalah banyak data bivariat $\left\{\left(x_{a}, y_{a}\right)\right\}$ dengan $x_{a} \leq x_{i}$ dan $y_{a} \leq y_{i}$

3. Untuk $j=1$, hitung

$$
\begin{aligned}
s_{n, j}^{*} & =\sum_{i=1}^{n}\left[H_{e}\left(x_{i}, y_{i}\right)-H_{\theta}\left(x_{i}, y_{i}\right)\right]^{2} \\
& =\sum_{i=1}^{n}\left[C_{e}\left(F\left(x_{i}\right), G\left(y_{i}\right)\right)-C_{\theta}\left(F\left(x_{i}\right), G\left(y_{i}\right)\right)\right]^{2}
\end{aligned}
$$

4. Untuk $j=j+1$, ulangi poin 1 sampai poin 3 , ke poin 5 jika $j=N+1$,

5. Hitung $p$-value, $\frac{\#\left(s_{n, j}^{*}>s_{n}\right)}{N}$ atau $\sum_{j=1}^{N}\left(\frac{I\left(s_{n, j}^{*}>s_{n}\right)}{N}\right)$, yang mana $I\left(s_{n, j}^{*}>s_{n}\right)$ adalah fungsi bernilai 1 untuk nilai $s_{n, j}^{*}>s_{n}$.

\section{METODOLOGI PENELITIAN}

Data yang digunakan pada penelitian ini adalah data IHK dan kur beli selama periode Mei 2012 sampai Juni 2017. Setelah data diperoleh, dilakukan pengolahan data sebagai berikut:

1. Uji stasioneritas pada data. 
2. Data yang belum stasioner maka akan dilakukan transformasi differencing berrdasarkan persamaan (1) dan (2).

3. Mengukur keterhubungan data yang sudah ditransformasi dengan menggunakan Kendall's Tau dan Spearman's Rho.

Pengolahan data bertujuan untuk mempermudah dalam melakukan analisis data. Kemudian setelah melakukan pengolahan data, langkah selanjutnya adalah analisis data sebagai berikut:

1. Estimasi parameter distribusi-distribusi marginal (IHK dan Kurs beli IDR-USD) berdasarkan Maximum Likelihood Estimation (MLE) yang mana dapat diperoleh dengan memaksimumkan fungsi likelihood.

2. Estimasi distribusi marginal (IHK dan Kurs IDR terhadap USD) berdasarkan KolmogorovSmirnov.

3. Estimasi parameter copula Archimedean berdasarkan Kendall's Tau. Untuk estimasi parameter copula Placket secara numerik berdasarkan Spearman's Rho.

4. Uji kecocokan copula melalui statistik Cramérvon Mises dan $p_{\text {value }}$ diperoleh dari parametric bootstrap.

\section{HASIL DAN PEMBAHASAN}

\subsection{Transformasi Data}

Setelah melalui pengolahan, data IHK dan kurs beli IDR-USD dapat disajikan pada Gambar 1. Gambar 1 merupakan scatterplot $(X, Y)$ dari data IHK $X$ dan kurs beli IDR-USD $Y$, hasil differencing dan histogram masing-masing peubah ditampilkan sebelah atas (IHK) dan kanan (kurs beli IDR-USD) scatterplot.

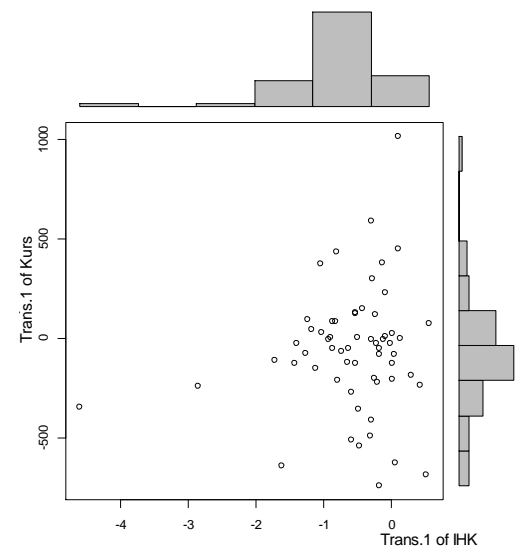

Gambar 1. Scatterplot Data $(X, Y)$

\subsection{Fungsi Distribusi Marginal Data}

Data yang digunakan adalah data hasil differencing yang mana diolah dengan menggunakan bantuan dari Easyfit. Easyfit menunjukkan bahwa data IHK dan kurs memiliki beberapa distribusi yang tertera pada Tabel 1.
Tabel 1. Parameter dan $p_{\text {value }}$ dari distribusi-distribusi marginal

\begin{tabular}{|c|c|c|c|c|}
\hline Dist. & Marg. & \multicolumn{2}{|c|}{ Parameter } & p-value (KS) \\
\hline Normal & \multirow{4}{*}{$X$} & $\mu=-0.5693$ & $\sigma=0.8015$ & 0.2293 \\
\hline Laplace & & $\mu=-0.5693$ & $\lambda=1.7645$ & 0.0626 \\
\hline Cauchy & & $\mu=-0.3667$ & $\sigma=0.3394$ & 0.3164 \\
\hline Logistik & & $\mu=-0.5693$ & $\sigma=0.4419$ & 0.2666 \\
\hline Normal & \multirow{4}{*}{$Y$} & $\mu=-61.633$ & $\sigma=308.69$ & 0.3420 \\
\hline Laplace & & $\mu=-61.633$ & $\lambda=0.0046$ & 0.9746 \\
\hline Cauchy & & $\mu=-46.64$ & $\sigma=127.83$ & 0.9634 \\
\hline Logistik & & $\mu=-61.633$ & $\sigma=170.19$ & 0.6039 \\
\hline
\end{tabular}

Estimasi parameter distribusi marginal-marginal dari data diperoleh dari Maximum Likelihood Estimation (MLE) dan uji kecocokan distribusi marginal berdasarkan statistik Kolmogorov-Smirnov.

\subsection{Estimasi Parameter dan Ukuran Keterhub- ungan antar Peubah}

Dalam penelitian ini ukuran keterhubungan yang digunakan untuk mengestimasi parameter $\theta$ copula Archimedean yaitu dengan melalui Kendall's Tau dan untuk copula Plackett menggunakan Spearman's Rho. Hasil estimasi parameter $\theta$ dan analisis korelasi antara IHK $(X)$ dan kurs beli IDR-USD $(Y)$ tertera pada Tabel 2.

Tabel 2. Hasil estimasi parameter $\theta$ copula dan nilai korelasi

\begin{tabular}{clc}
\hline & Jenis Copula & $\begin{array}{c}\text { Parameter } \\
(\boldsymbol{\theta})\end{array}$ \\
\hline & Clayton & 0.0494 \\
Kendall's Tau & Gumbel & 1.0247 \\
$(\tau=0.0241)$ & Ali-Mikhail-Haq & 0.2172 \\
& Frank & 0.1056 \\
\hline Spearman's Rho & Plackett & 1.1107 \\
$(\rho=0.0350)$ & & \\
\hline
\end{tabular}

Berdasarkan Tabel 2, dapat dilihat bahwa keterhubungan antara IHK dan kurs beli IDR-USD sangat kecil yang berarti saling bebas.

\subsection{Uji Kecocokan Copula}

Uji kecocokan copula dilakukan berdasarkan distribusi-distribusi yang telah diperoleh pada Tabel 1 dan melalui statistik Crame`r-von Mises $\left(S_{n}\right)$ beserta $p_{\text {value }}$ yang diperoleh dari parametric bootstrap. Hasil perhitungan $S_{n}$ disajikan pada Tabel 3. Berdasarkan perhitungan yang disajikan pada Tabel 3 , terdapat 80 model copula dari 16 pasangan distribusi-distribusi marginal. Selanjutnya akan dilakukan pembangkitan statistik uji $S_{n}$ melalui parametric bootstrap. Melalui simulasi parametric bootstrap akan diperoleh 1000 nilai statistik uji $S_{n}$ untuk uji kecocokan distribusi-distribusi marginal dengan copula. 
Tabel 3. Hasil perhitungan $S_{n}$

\begin{tabular}{cllllll}
\hline \multicolumn{2}{c}{ Distribusi } & \multicolumn{5}{c}{ Jenis Copula } \\
\hline$X$ & $Y$ & Clayton & Gumbel & Frank & AMH & Placket \\
\hline Cauchy & Laplace & 0.1048 & 0.1341 & 0.1349 & 0.1350 & 0.1357 \\
Cauchy & Cauchy & 0.1222 & 0.1611 & 0.1622 & 0.1623 & 0.1633 \\
Cauchy & Logistik & 0.1524 & 0.1815 & 0.1824 & 0.1825 & 0.1833 \\
Cauchy & Normal & 0.1843 & 0.2131 & 0.2141 & 0.2142 & 0.2150 \\
Logistik & Laplace & 0.1236 & 0.0820 & 0.0834 & 0.0834 & 0.0828 \\
Logistik & Cauchy & 0.1065 & 0.0781 & 0.0797 & 0.0797 & 0.0794 \\
Logistik & Logistik & 0.1465 & 0.1071 & 0.1092 & 0.1093 & 0.1086 \\
Logistik & Normal & 0.1682 & 0.1294 & 0.1318 & 0.1319 & 0.1312 \\
Normal & Laplace & 0.1405 & 0.1019 & 0.1040 & 0.1041 & 0.1034 \\
Normal & Cauchy & 0.1315 & 0.1048 & 0.1124 & 0.1071 & 0.1068 \\
Normal & Logistik & 0.1652 & 0.1286 & 0.1313 & 0.1314 & 0.1307 \\
Normal & Normal & 0.1875 & 0.1514 & 0.1544 & 0.1546 & 0.1539 \\
Laplace & Laplace & 0.1369 & 0.0851 & 0.0851 & 0.0851 & 0.0845 \\
Laplace & Cauchy & 0.1053 & 0.0693 & 0.0695 & 0.0695 & 0.0692 \\
Laplace & Logistik & 0.1539 & 0.1053 & 0.1060 & 0.1060 & 0.1054 \\
Laplace & Normal & 0.1731 & 0.1252 & 0.1263 & 0.1263 & 0.1257 \\
\hline
\end{tabular}

Setelah mendapatkan nilai simulasi $S_{n}$ sebanyak 1000 kali, langkah selanjutnya adalah mengulangi simulasi parametric bootstrap sebanyak 100 kali untuk menaksir rata-rata $p$-value dan seberapa banyak $H_{0}$ diterima dalam pengulangan tersebut. Tabel 4 menunjukkan jumlah $H_{0}$ yang diterima dan rata-rata nilai $p$ value setelah dilakukan pengulangan sebanyak $100 \mathrm{kali}$.

Tabel 4. Hasil Pengulangan Parametric Bootstrap 100 Kali untuk p-value Cramér-von Mises $\widehat{S_{n}}$

\begin{tabular}{|c|c|c|c|c|c|c|}
\hline Marg. & Hasil & $\begin{array}{l}\text { Clay- } \\
\text { ton }\end{array}$ & $\begin{array}{c}\text { Gum- } \\
\text { bel }\end{array}$ & Frank & $\mathrm{AMH}$ & Placket \\
\hline \multirow{2}{*}{$\begin{array}{l}\text { Cauchy } \\
\text { Laplace }\end{array}$} & $\mathrm{H}_{0}$ acc & 0 & 0 & 0 & 0 & 0 \\
\hline & p-val & 0.0062 & 0.0038 & 0.0044 & 0.0046 & 0.0043 \\
\hline \multirow{2}{*}{$\begin{array}{l}\text { Cauchy } \\
\text { Cauchy }\end{array}$} & $\mathrm{H}_{0}$ acc & 0 & 0 & 0 & 0 & 0 \\
\hline & p-val & 0.0020 & 0.0014 & 0.0019 & 0.0017 & 0.0016 \\
\hline \multirow{2}{*}{$\begin{array}{c}\text { Cauchy } \\
\text { Logis. }\end{array}$} & $\mathrm{H}_{0}$ acc & 100 & 78 & 100 & 100 & 96 \\
\hline & $\mathrm{p}$-val & 0.0758 & 0.0562 & 0.0649 & 0.0672 & 0.0646 \\
\hline \multirow{2}{*}{$\begin{array}{l}\text { Cauchy } \\
\text { Normal }\end{array}$} & $\mathrm{H}_{0}$ acc & 100 & 100 & 100 & 100 & 100 \\
\hline & p-val & 0.1577 & 0.1297 & 0.1465 & 0.1482 & 0.1434 \\
\hline \multirow{2}{*}{$\begin{array}{l}\text { Logis. } \\
\text { Laplace }\end{array}$} & $\mathrm{H}_{0}$ acc & 100 & 100 & 100 & 100 & 100 \\
\hline & p-val & 0.9620 & 0.9576 & 0.9592 & 0.9598 & 0.9590 \\
\hline \multirow{2}{*}{$\begin{array}{l}\text { Logis. } \\
\text { Cauchy }\end{array}$} & $\mathrm{H}_{0}$ acc & 100 & 100 & 100 & 100 & 100 \\
\hline & p-val & 0.8972 & 0.8961 & 0.8976 & 0.8948 & 0.8939 \\
\hline \multirow{2}{*}{$\begin{array}{l}\text { Logis. } \\
\text { Logis. }\end{array}$} & $\mathrm{H}_{0}$ acc & 100 & 100 & 100 & 100 & 100 \\
\hline & p-val & 0.9291 & 0.9237 & 0.9270 & 0.9279 & 0.9255 \\
\hline \multirow{2}{*}{$\begin{array}{l}\text { Logis. } \\
\text { Normal }\end{array}$} & $\mathrm{H}_{0}$ acc & 100 & 100 & 100 & 100 & 100 \\
\hline & p-val & 0.8920 & 0.8838 & 0.8889 & 0.8880 & 0.8879 \\
\hline \multirow{2}{*}{$\begin{array}{l}\text { Normal } \\
\text { Laplace }\end{array}$} & $\mathrm{H}_{0}$ acc & 100 & 100 & 100 & 100 & 100 \\
\hline & p-val & 0.8643 & 0.8548 & 0.8585 & 0.8580 & 0.8573 \\
\hline \multirow{2}{*}{$\begin{array}{l}\text { Normal } \\
\text { Cauchy }\end{array}$} & $\mathrm{H}_{0}$ acc & 100 & 100 & 100 & 100 & 100 \\
\hline & p-val & 0.7051 & 0.7086 & 0.6069 & 0.7090 & 0.7023 \\
\hline \multirow{2}{*}{$\begin{array}{l}\text { Normal } \\
\text { Logis. }\end{array}$} & $\mathrm{H}_{0}$ acc & 100 & 100 & 100 & 100 & 100 \\
\hline & p-val & 0.8605 & 0.8532 & 0.8597 & 0.8597 & 0.8443 \\
\hline \multirow{2}{*}{$\begin{array}{l}\text { Normal } \\
\text { Normal }\end{array}$} & $\mathrm{H}_{0}$ acc & 100 & 100 & 100 & 100 & 100 \\
\hline & p-val & 0.8406 & 0.8314 & 0.8390 & 0.8388 & 0.8371 \\
\hline \multirow{2}{*}{$\begin{array}{l}\text { Laplace } \\
\text { Laplace }\end{array}$} & $\mathrm{H}_{0}$ acc & 100 & 100 & 100 & 100 & 100 \\
\hline & p-val & 0.9796 & 0.9713 & 0.9757 & 0.9753 & 0.9755 \\
\hline \multirow{2}{*}{$\begin{array}{l}\text { Laplace } \\
\text { Cauchy }\end{array}$} & $\mathrm{H}_{0}$ acc & 100 & 100 & 100 & 100 & 100 \\
\hline & p-val & 0.9702 & 0.9629 & 0.9680 & 0.9673 & 0.9661 \\
\hline \multirow{2}{*}{$\begin{array}{c}\text { Laplace } \\
\text { Logis. }\end{array}$} & $\mathrm{H}_{0}$ acc & 100 & 100 & 100 & 100 & 100 \\
\hline & p-val & 0.9556 & 0.9462 & 0.9522 & 0.9520 & 0.9509 \\
\hline \multirow{2}{*}{$\begin{array}{l}\text { Laplace } \\
\text { Normal }\end{array}$} & $\mathrm{H}_{0}$ acc & 100 & 100 & 100 & 100 & 100 \\
\hline & p-val & 0.9217 & 0.9086 & 0.9174 & 0.0082 & 0.9148 \\
\hline
\end{tabular}

Selanjutnya dari 80 model copula tersebut akan dipilih $p_{\text {value }}$ tertinggi untuk masing-masing copula yang mana akan disajikan pada Tabel 5 .
Tabel 5. Hasil $p_{\text {value }}$ melalui parametric bootstrap

\begin{tabular}{|c|c|c|}
\hline \multirow{2}{*}{ Copula } & \multicolumn{2}{|c|}{ Distribusi } \\
\hline & $X \sim$ Laplace & $Y \sim$ Laplace \\
\hline Clayton & & \\
\hline Gumbel & & \\
\hline Frank & & \\
\hline $\mathrm{AMH}$ & & \\
\hline Plackett & & \\
\hline
\end{tabular}

Setelah dilakukan pengulangan dengan nilai signifikasi 0.05 , model copula yang memiliki rata-rata $p_{\text {value }}$ tertinggi adalah copula Clayton dengan distribusi bivariat Laplace yaitu 0.9796. Histogram simulasi $S_{n}$ dengan $X \sim$ Laplace dan $Y \sim$ Laplace untuk copula Clayton terdapat pada Gambar 2 dan fungsi distribusi, densitas, dan contour model copula Clayton disajikan pada Gambar 3.

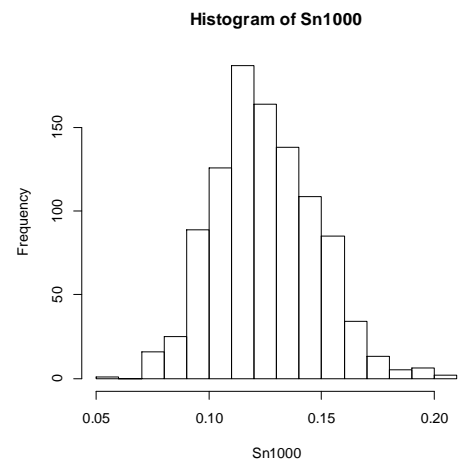

Gambar 2. Histogram $S_{n}$ (1000 nilai) dengan $X \sim$ Laplace dan $Y \sim$ Laplace untuk copula Clayton.
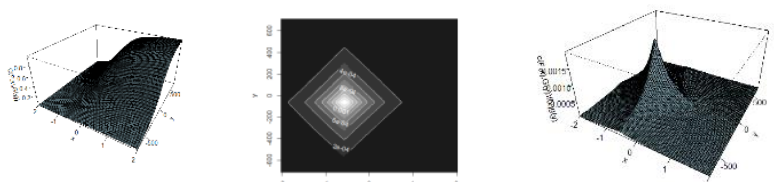

Fungsi Distribusi Contour Densitas Fungsi Densitas Gambar 3. Copula Clayton untuk distribusi bivariat Laplace.

\section{KESIMPULAN}

Penelitian ini mempelajari bagaimana hubungan antara IHK dan kurs beli IDR-USD dengan pendekatan copula. Beberapa hal yang dapat ditarik menjadi kesimpulan pada penelitian ini yaitu keterhubungan kedua peubah berdasarkan Kendall's Tau dan Spearman's Rho sangat kecil yang berarti saling bebas atau hampir tidak memiliki keterhubungan. Copula dapat mendeteksi perilaku data melalui uji kecocokan ukuran statistik Cramér-von Mises $S_{n}$ berdasarkan $p_{\text {value }}$ tertinggi. Pola hubungan IHK dan kurs beli IDR-USD ditunjukkan dengan model copula Clayton dengan distribusi bivariat Laplace yang mana model tersebut dapat menggambarkan keterhubungan data yang terbaik. Pada 
penelitian ini diperoleh distribusi bivariat Laplace dengan copula. Berdasarkan model copula Clayton dengan distribusi bivariat Laplace, terdapat hubungan antara IHK dan kurs beli IDR-USD positif.

\section{DAFTAR PUSTAKA}

[1] N. Soemartojo, Statistik untuk Manajemen dan Ekonomi, Jakarta, 1982.

[2] K. N. Anisa, dan Sutikno, "Analisis Hubungan Curah Hujan dan Indikator El-Nino Southern Oscillation di Sentra Produksi Padi Jawa Timur dengan Pendekatan Copula”. Skripsi, Institut Teknologi Sepuluh Nopember, Surabaya, Vol. 4, No. 1. 2015.

[3] Heriyanto, dan M. Chen, "Analisis Pengaruh Indeks Harga Konsumen, Jumlah Uang Beredar (M1), Kurs Rupiah, dan Indeks S\&P 500 terhadap Indeks Harga Saham Gabungan: Studi Empiris pada Bursa Efek Indonesia”. Skripsi, Jurnal Nominal, Vol. 3, No. 2. 2014.

[4] R. B. Nelsen, An Introduction to Copulas, New York: Springer Series in Statistics, 2006.

[5] Juanda, Bambang dan Junaidi. Ekonometrika Deret Waktu, IPB Press, Bogor. 2012.

[6] W. R. Blischke, M. R. Karim, dan D. N. P. Murthy, Warranty Data Collection and Analysis, London: Springer Series in Reliability Eng., 2011, bab 2.

[7] L. R. Sasongko, “Copula untuk Memodelkan Kegagalan Dua Dimensi pada Produk Bergaransi dengan Strategi Penggantian,” M.Si. tesis, Program Pascasarjana Magister Aktuaria, Institut Teknologi Bandung, Bandung, 2014.

[8] Genest, C., Remillard, B., dan Beaudoin, D. (2009): Goodness-of-fit Tests for Copulas: a review and a power study, Insurance: Mathematics and Economics, 44, 199-214.

[9] D. B. Nugroho, "Metode Numerik", unpublished.

\section{Lampiran A. Fungsi Distribusi Univariat}

Pada bagian ini akan diberikan fungsi distibusi univariat yang digunakan dalam penelitian ini. Misalkan $X$ adalah peubah acak kontinu dengan fungsi distribusi $F_{X}$.

1. Cauchy, $X \sim \operatorname{Cauchy}(\mu, \sigma)$.

$$
F_{x}(x)=\frac{1}{\pi} \arctan \left(\frac{x-\mu}{\sigma}\right)+0.5, \quad x \in[0,1]
$$

2. Logistik, $X \sim \operatorname{Logistik}(\mu, \sigma)$

$$
F_{x}(x)=\frac{1}{1+\exp \left(-\left(\frac{x-\mu}{\sigma}\right)\right)},-\infty<x<\propto
$$

3. Normal, , $X \sim N\left(\mu, \sigma^{2}\right)$

$$
F_{X}(x)=\frac{1}{x \sigma \sqrt{2 \pi}} \int_{-\infty}^{x} \exp \left\{-\frac{1}{2}\left(\frac{\ln t-\mu}{\sigma}\right)^{2}\right\} d t, x \in[0, \infty)
$$

4. Laplace, $X \sim \operatorname{Laplace}(\mu, \lambda)$

$$
F_{x}(x)= \begin{cases}\frac{1}{2} \exp (-\lambda(\mu-x)) & x \leq \mu \\ 1-\frac{1}{2} \exp (-\lambda(x-\mu)) & x>\mu\end{cases}
$$

Elvina Luxviantono (662014011@student.uksw.edu) lahir

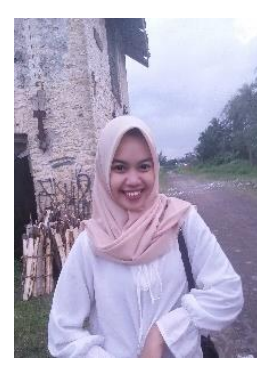
di Salatiga, pada tanggal 17 Mei 1996 adalah mahasiswa yang sedang menempuh pendidikan tinggi di Program Studi Matematika, Universitas Kristen Satya Wacana (UKSW) Salatiga. Tahun 2018 merupakan tahun terakhir ia menempuh studi. Makalah ini merupakan hasil penelitian skripsinya yang dipublikasikan.

Adi Setiawan (Adi setia 03@yahoo.com) lahir di Sra-

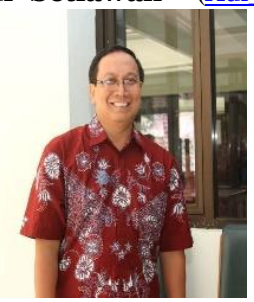
gen,pada tanggal 26 Februari 1969. Pada tahun 1991 ia menyelesaikan studi S-1 di Universitas Gadjah Mada Jogjakarta. Tahun 1992 dan 2007 merupakan tahun ketika ia berhasil menyelesaikan studi lanjut S-2 dan S-3 di Vrije Universiteit Amsterdam, the Netherlands pada tahun 1997

dan 2007.

Dia telah bekerja di UKSW sejak tahun 1992 sebagai tenaga Pengajar Akademik (Dosen) Statistika pada Program Studi Matematika, Fakultas Sains dan Matematika, UKSW.

\section{Leopoldus Ricky Sasongko}

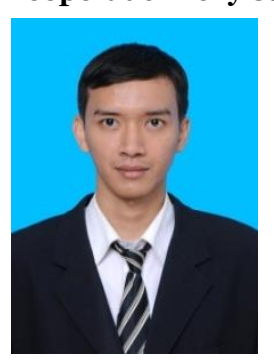

(leopoldus.sasongko@staff.uksw.edu.) lahir di Ketapang, Kalimantan Barat, pada tanggal 14 November 1989. Pada tahun 2011, gelar Sarjana Sains (S.Si) diperoleh dari Universitas Kristen Satya Wacana (UKSW) Salatiga. Gelar Magister Sains (M.Si) didapat dari Program Pascasarjana Magister Aktuaria, Institut Teknologi Bandung (ITB), pada tahun 2014.

Ia bekerja di UKSW sejak tahun 2011 sebagai Calon Pengajar Akademik (Dosen) di Program Studi Matematika, Fakultas Sains dan Matematika, UKSW. Saat ini, ia menjadi Pengajar Akademik Tetap di UKSW.

Sasongko, M.Si, merupakan salah satu anggota Asosiasi Matematikawan Indonesia, IndoMS. Bidang penelitian yang digeluti adalah Matematika Aktuaria dan Garansi (Warranty). Salah satu makalah hasil penelitian adalah The Estimation of Renewal Functions Using the Mean Value Theorem for Integrals (MeVTI) Method yang terpublikasi di Jurnal Matematika dan Aplikasi deCartesiaN, Universitas Sam Ratulangi (UNSRAT). 